Scientific journal

PHYSICAL AND MATHEMATICAL EDUCATION

Has been issued since 2013

Науковий журнал

ФІЗИКО-МАТЕМАТИЧНА ОСВІТА

Видається з 2013.

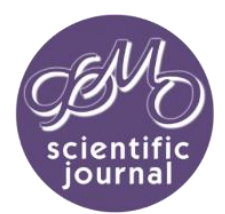

e-ISSN 2413-158X

DOI: $10.31110 / 2413-1571$

https://fmo-journal.org/

DOI 10.31110/2413-1571-2021-032-6-005

Удк 378. 371: 53

\section{СИЛАБУС \\ ЯК ЗАСІБ ПІДВИЩЕННЯ \\ ЯКОСТІ ФАХОВОЇ ПІДГОТОВКИ СТУДЕНТІВ \\ У ЗАКЛАДАХ ВИЩОї БУДІВЕЛЬНОї ОСВІТИ}

\author{
Тетяна ПЕТРУньОК \\ Київський національний університет будівництва \\ і архітектури, Україна \\ petrunok.tb@knuba.edu.ua \\ https://orcid.org/0000-0002-3261-32963261-3296 \\ ЛюдМила БЛАГОДАРЕНКО \\ Національний педагогічний університет \\ імені М.П. Драгоманова, Україна \\ kzf@ukr.net \\ https://orcid.org/0000-0002-5501-5416
}

\begin{abstract}
АНОТАЦІЯ
Формулювання проблеми. У статті досліджується проблема створення навчально-методичного забезпечення нового типу, використання якого нерозривно пов'язане з упровадженням сучасних освітніх моделей навчання. Наголошено, що багатовекторність підготовки студентів будівельних спеціальностей вимагає успішного формування компетентностей з різних дисциплін як загального, так $i$ професійного циклів підготовки, тому постає проблема визначення змісту поняття силабусу як засобу підвищення якості фахової підготовки студентів у закладах вищої будівельної освіти.

Матеріали і методи. В основу дослідження покладено аналіз наукових напрачювань вітчизняних вчених, систематизовано то узагальнено результати педагогічного спостереження за освітнім процесом у закладах вищої будівельної освіти. Опрацьовано стандарт вищої освіти України у даній галузі та для певно спеціальності з урахуванням рівнів вищої освіти (бакалавр або магістр), законодавчі та нормативні документи, які використовуються для забезпечення якості освіти.

Результати. Визначено зміст поняття силабусу як засобу підвищення якості фахової підготовки. Обгрунтовано, що силабус - це навчальна програма дисципліни, яка дозволяє індивідуалізувати та диференціювати освітній процес, а також забезпечити для кожного студента можливості побудови етапів власної навчальної діяльності та керування цими етапами уїх динаміці. Конкретизовано, що силабус створюється відповідно до стандарту вищої освіти України у даній галузі та для певної спеціальності з урахуванням освітнього ступеня (бакалавр або магістр). Показано, що структура силабусугрунтується на загальнодидактичних принципах, а при його створенні обов'язково повинні бути враховані сучасні тенденції розвитку будівельної галузі, характеристики видів та об'єктів професійної діяльності.

Висновки. Обгрунтовано, що моделювання силабусу $\epsilon$ багатоаспектним і передбачає досягнення основних освітніх цілей. Констатовано, що основний кониептуальний аспект впровадження силабусу грунтується на єдності свідомості та діяльності, що дозволяє не тільки забезпечити знання з конкретної дисиипліни, але й сформувати особистість, підготовлену до професійної діяльності. Показано, що головне призначення силабусу полягає у регулюванні освітнього процесу, забезпеченні гнучкості та адаптивності моделей навчання.

ключовІ СловА: силабус; підготовка фахівців будівельних спеціальностей; заклади вищої будівельної освіти; навчально
\end{abstract} методичне забезпечення.

\section{SILABUS \\ AS A MEANS OF IMPROVING \\ THE QUALITY OF PROFESSIONAL TRAINING OF STUDENTS IN INSTITUTIONS OF HIGHER BUILDING EDUCATION}

\author{
Tetiana PETRUNOK ${ }^{\square}$ \\ Kyiv National University of Construction i architecture, \\ Ukraine \\ petrunok.tb@knuba.edu.ua \\ https://orcid.org/0000-0002-3261-32963261-3296 \\ Ludmila BLAGODARENKO \\ National Pedagogical Dragomanov University, \\ Ukraine \\ kzf@ukr.net \\ https://orcid.org/0000-0002-5501-5416
}

\begin{abstract}
Problem formulation. The article examines the problem of creating a new type of educational and methodological support, the use of which is inextricably linked with the introduction of modern educational models of learning. It is emphasized that the multi-vector training of students of construction specialties requires successful formation of competencies in various disciplines of both general and professional cycles of training, so there is a problem of determining the content of syllabus as a means of improving the quality of professional training in higher education

Materials and methods. The study is based on the analysis of: scientific developments of domestic scientists, systematized and summarized the results of pedagogical observation of the educational process in institutions of higher construction education; standard of higher education in Ukraine in this field and for a particular specialty, taking into account the levels of higher education (bachelor's or master's degree), legislative and regulatory documents used to ensure the quality of education.

Results. The content of the concept of syllabus as a means of improving the quality of professional training is determined. It is substantiated that the syllabus is a curriculum of the discipline, which allows individualizing and differentiating the educational process, as well as providing each student with opportunities to build stages of their own learning activities and manage these stages in their dynamics. It is specified that the syllabus is created in accordance with the standard of higher education of Ukraine in this field and for a certain specialty, taking into account the educational degree (bachelor or master). It is shown that the structure of the syllabus is based on general didactic principles, and its creation must take into account current trends in the construction industry, the characteristics of types and objects of professional activity.

Conclusions. It is substantiated that the simulation of the syllabus is multifaceted and involves the achievement of basic educational goals. It is stated that the main conceptual aspect of the introduction of syllabus is based on the unity of consciousness and activity, which allows not only to provide knowledge of a particular discipline, but also to form a person prepared for professional activities. It is shown that the main purpose of the syllabus is to regulate the educational process, ensure flexibility and adaptability of learning models.
\end{abstract}

KEYWORDS: syllabus; training of specialists in construction specialties; institutions of higher construction education; educational and methodological support.

Для цитування: Петруньок Т., Благодаренко Л. Силабус як засіб підвищення якості фахової підготовки студентів уз Петруньок, Т. \& Благодаренко, Л. (2021). Силабус як засіб пілвищення якості фахової підготовки стүдентів у закладах вищої будівельної освіти. Фізикоматематична освіта, 32(6). 29-33. https://doi.org/10.31110/2413-1571-2021-032-6-005

For citation: Petrunok, T., \& Blagodarenko, L. (2021). Silabus as a means of improving the quality of professional training of students in institutions of higher building education. Physical and Mathematical Education, 32(6), 29-33. https://doi.org/10.31110/2413-1571-2021-032-6-005 Petrunok, T., \& Blagodarenko, L. (2021). Sylabus yak zasib pidvyshchennia yakosti fakhovoi pidhotovky studentiv u zakladakh vyshchoi budivelnoi osvity [Silabus as a means of improving the quality of professional training of students in institutions of higher building education]. Fizyko-matematychna osvita - Physical and Mathematical Education, 32(6), 29-33. https://doi.org/10.31110/2413-1571-2021-032-6-005 
ВСТУП

Постановка проблеми. Від якості вищої освіти залежить рівень економічного розвитку країни, а відтак і добробут iї громадян. Важливим чинником $€$ розбудова внутрішньої системи якості освіти у закладах вищої освіти, а також інтернаціоналізація української системи вищої освіти. У закладах вищої будівельної освіти повинна здійснюватися підготовка конкурентоспроможних фахівців для високотехнологічного та інноваційного розвитку країни (Петруньок та Благодаренко, 2021). Сьогодні заклади вищої будівельної освіти є лідерами у підготовці фахівців для будівельної галузі. Дипломовані інженери-будівельники працюють у багатьох провідних профільних компаніях та установах. На молодих фахівців існує сталий попит на ринку праці не лише в Україні, але й за кордоном, а тому забезпечення якості вищої освіти $€$ пріоритетом успішної державної освітньої політики країн Європи та інших розвинених країн світу.

Структура діяльності майбутніх фахівців будівельних спеціальностей є складною і розгалуженою та містить декілька взаємопов' язаних компонентів, зокрема:

- виробничо-управлінський компонент, який передбачає розрахунки, вибір і налаштування обладнання, керування технологічним процесом, використання комп'ютерної графіки для побудови моделей споруд;

- сертифікаційний компонент, який передбачає стандартизацію та сертифікацію будинків та інших споруд, а також розроблення нових підходів до сертифікації відповідно до умов процесу забудови;

- контрольно-оцінювальний компонент, який зумовлений необхідністю оцінювання властивостей i характеристик будівельних матеріалів та правильності вибору технологій будівництва, контролю за ходом процесу забудови та за наданням послуг відповідно до вимог замовника, контролю за якістю виконаних робіт;

- експериментально-дослідницький компонент, який передбачає здійснення досліджень у галузі будівництва, дослідження можливостей удосконалення технологій будівництва, дослідження якості побудованих об'єктів та їх випробування.

Але говорити про високий рівень загальнонаукової підготовки та фахової компетентності інженера-будівельника можна лише у тому випадку, якщо у нього сформовані наукове і логічне мислення, ґрунтовна універсальна технічна база. Слід зазначити, що у закладах вищої будівельної освіти підготовка студентів потребує особливої уваги, оскільки майбутній фахівець будівельної галузі $\epsilon$ інженером-будівельником широкої спеціалізації, а це вимагає від нього ґрунтовних знань у різних сферах будівельної галузі.

Аналіз актуальних досліджень. Зрозуміло, що у закладах вищої будівельної освіти підготовка студентів має здійснюватися на високопрофесійному рівні (Москов, 2016). Актуалізується проблема визначення підходів до оптимізації самостійної роботи студентів, посилення її ролі, до розробки засобів та інструментарію, форм та методів навчання, що забезпечують органічне засвоєння змісту навчальних дисциплін. Тому на викладачів покладена важлива місія формування у майбутніх фахівців-будівельників такого рівня фахової підготовки, який забезпечить успішне професійне i соціальне становлення з урахуванням потреб економіки і суспільства в цілому. А це, у свою чергу, зумовлює необхідність створення навчально-методичного забезпечення нового покоління, використання якого нерозривно пов'язане 3 упровадженням сучасних освітніх моделей навчання.

У сучасних умовах модернізації освіти змінюються цілі і задачі освітнього процесу. Використовуються сучасні методи навчання, які $є$ активними методами у формування знань, вмінь та компетентностей і засновані на взаємодії учасників навчального процесу та їх залученні у навчальний процес, а не лише на пасивному сприйнятті теоретичного матеріалу. Посилюється активізація ролі студентів у навчальному процесі: самоорганізація, залучення студентів в управління власним освітнім маршрутом. Тому і виникає потреба використання силабусу як своєрідного плану-конспекту навчальної дисципліни.

Проблемами упровадження в освітній процес силабусу для організації самостійної діяльності студентів займалися такі науковці, як Н.В. Булах О.І. Ваганова, А.В. Хижная, О.В. Трутанова, М.М. Гладкова, Ю.Б. Лунєва. Аналіз опрацьованих джерел свідчить про те, що недостатньо уваги приділялося питанню використання силабусу як засобу для підвищення якості фахової підготовки студентів у закладах вищої будівельної освіти, тому метою статті є обґрунтування доцільності використання силабусу як засобу підвищення якості навчально-методичного та інформаційно-технічного забезпечення освітньої діяльності для фахової підготовки інженерів-будівельників.

\section{МЕТОДИ ДОСЛІДЖЕННЯ}

В основу дослідження покладено аналіз наукових напрацювань вітчизняних вчених, систематизовано та узагальнено результати педагогічного спостереження за освітнім процесом у закладах вищої будівельної освіти. Опрацьовано стандарт вищої освіти України у даній галузі та для певної спеціальності з урахуванням рівнів вищої освіти (бакалавр або магістр), законодавчі та нормативні документи, які використовуються для забезпечення якості освіти.

Для досягнення мети використано такі методи: аналіз, систематизація та інтерпретація результатів педагогічних досліджень, законодавчих і нормативних документів, педагогічне спостереження.

\section{РЕЗУЛЬТАТИ ДОСЛІДЖЕННЯ}

Силабус - це навчальна програма дисципліни, яка дозволяє індивідуалізувати та диференціювати освітній процес та забезпечити для кожного студента можливості побудови етапів власної навчальної діяльності та керування цими етапами у їх динаміці. Для досягнення запланованих цілей у своїй педагогічній діяльності кожен викладач розробляє принципово новий комплекс навчально-методичного забезпечення, а саме силабус як засіб забезпечення якісної підготовки студентів під час освітнього процесу у закладах вищої будівельної освіти, у якому відображено у доступній формі повну інформацію про навчальну дисципліну. Силабус створюється відповідно до стандарту вищої освіти України у даній галузі та для певної спеціальності з урахуванням рівнів вищої освіти (бакалавр або магістр). Структура силабусу ґрунтується на загально дидактичних принципах, основними з яких є модульність, дієвість та гнучкість, динамічність та 
оперативність знань. При створенні силабусу обов'язково повинні бути враховані сучасні тенденції розвитку будівельної галузі, стратегії держави у розв'язанні проблемних питань, характеристики видів і об'єктів професійної діяльності.

Моделювання силабусу $є$ багатоаспектним і передбачає виконання таких основних освітніх цілей, як формування структури навчальної діяльності та навчальних дій з урахуванням нормативної моделі інженера-будівельника; формування і розвиток способів професійної діяльності з урахуванням особистісних якостей студента. Що стосується основного концептуального аспекту силабусу, то він ґрунтується на загальноприйнятій методологічній основі - єдності свідомості та діяльності, що дозволяє не тільки забезпечити знання з конкретної дисципліни, але й сформувати особистість, підготовлену до професійної діяльності. Головне призначення силабусу - регулювання освітнього процесу, забезпечення становлення і розвитку особистості у ході навчально-пізнавальної діяльності, поєднання теорії із практикою, забезпечення гнучкості та адаптивності моделей навчання, застосування коригувальних засобів відповідно до індивідуальних результатів навчання, визначення алгоритмів освітнього процесу з урахуванням закономірностей побудови відповідних моделей і способів їх реалізації на продуктивному рівні.

Отже, силабус $є$ траєкторією руху студента, основою організації його роботи під час навчання, стислим описом навчальної дисципліни, частиною навчально-методичного забезпечення освітнього процесу, забезпечує становлення студентів та формує мотивацію до навчання, підвищує якість підготовки студентів у закладах вищої будівельної освіти (Чепурна, 2020). Цей документ визначає призначення та роль дисципліни у якісній підготовці студентів, мету їі вивчення, зміст навчального матеріалу та форми організації навчального процесу, встановлює регламент діяльності викладача та студента у ході освітнього процесу. Використання в освітньому процесі силабусу як засобу підвищення якості підготовки студентів дозволяє ґрунтовно сформувати систему знань, здійснити вплив на формування у студентів вмінь набувати нові знання та застосовувати їх для вирішення проблем, пов язаних з професійною діяльністю. Розробка та реалізація силабусу в освітньому процесі дозволяє забезпечувати максимальну відповідність якості підготовки студентів запитам роботодавців.

Враховуючи психологічні особливості сучасних студентів, їх відношення до навчання, відсутність навичок пізнавальної діяльності, викладачу складно в організації освітнього процесу у закладах вищої будівельної освіти відповідно до вимог компетентнісного підходу (Gnitetskaya, 2004). Використання силабусу в освітньому процесі забезпечує якісну підготовку студентів, оскільки оптимізує спільну діяльність викладача і студентів, при цьому підвищується рівень засвоєння навчальної дисципліни, відкриваються нові можливості для самоосвіти, підсилюється прагнення до професійної діяльності за рахунок доступності інформації. Зрозуміло, що силабус виконує основну задачу це забезпечення залучення студентів в освітній процес. Тому слід звернути увагу на те, що цей документ являє собою змістовну інформацію про дисципліну та має бути написаний доступною мовою, щоб кожен студент чітко розумів мету вивчення навчальної дисципліни. Необхідно раціонально планувати і організовувати освітній процес, оскільки це $\epsilon$ найважливішою умовою його ефективності. Рівень організації навчальної діяльності та якість підготовки студентів у закладах вищої будівельної освіти безпосередньо пов'язані з ефективністю навчання студентів і успішністю засвоєння ними навчальних дисциплін. Тому доречно після закінчення вивчення дисципліни ставити студентам такі запитання: «Чи зрозумілим був зміст силабусу?», «Які можна внести пропозиції до його змісту ?» та ін. Правильна організація навчальної діяльності студентів - це запорука формування умінь і навичок в оволодінні, вивченні, засвоєнні і систематизації набутих знань, забезпечення високого рівня фахової підготовки та успішності у процесі навчання, що можливо лише при використанні силабусу у освітньому процесі.

Силабус, як узагальнення змісту навчальної дисципліни, повинен бути коротким і зрозумілим для студента, тому його побудова має максимально відповідати на запитання студента про навчальну дисципліну і, водночас, відображати необхідні складові та їх взаємозв'язок. Силабус поєднує в собі сучасний структурований зміст дисципліни, який має засвоїти студент, що передбачає не стільки засвоєння предметних знань, скільки розвиток компетентностей, що у свою чергу формує професійні якості у підготовці фахівців.

У своїй структурі силабус повинен містити такі основні складові:

$>$ назва дисципліни, галузь знань, шифр спеціалізації за освітньою програмою, навчальний рік, освітній рівень, форма навчання, спеціальність, назва освітньої програми, статус освітньої компоненти; семестр вивчення дисципліни, мову викладання, пререквізити (базові знання необхідні для успішного засвоєння дисципліни);

> ПІБ, науковий ступінь, вчене звання, посада, контактна інформація, наукові інтереси викладача;

$>$ мета курсу, програмні результати навчання (повинні відповідати компетентностям), методи перевірки навчального ефекту, форми проведення занять; посилання на загальні та професійні (фахові) компетентності, що прописані у стандарті вищої освіти для відповідної галузі знань, спеціальності, рівня вищої освіти та ступеня вищої освіти;

$>$ структура курсу, що містить види занять та розподіл годин, загальну кількість кредитів, кількість годин аудиторного навантаження, відведених на проведення занять згідно робочого навчального плану на навчальний для даної дисципліни;

> зміст курсу, що містить розподіл тем по усім видам занять (вказано теми лекційних, практичних, лабораторних занять, самостійної роботи, індивідуальної контрольної роботи);

$>$ система оцінювання навчальних досягнень за національною шкалою ЕСТS (кількість балів за відповідний вид навчальної діяльності);

$>$ умови допуску до підсумкового контролю (заліку, екзамену), які чітко визначають вимоги до учасника навчального процесу (наприклад: відвідування лекційних занять (онлайн / офлайн), відвідування практичних занять, активно відповідати та розв 'язувати задачі на заняттях, виконання та оформлення лабораторних робіт; дотримання термінів виконання контрольної роботи; виконання самостійної роботи; дотримання умов академічної доброчесності);

$>$ політика щодо академічної доброчесності (вказати сукупність етичних принципів та визначених законом правил, якими мають керуватися учасники освітнього процесу під час навчання, а саме: самостійне виконання навчальних завдань, завдань поточного та підсумкового контролю результатів навчання; посилання на джерела інформації у разі 
використання ідей, розробок, тверджень, відомостей; дотримання норм законодавства про авторське право і суміжні права; надання достовірної інформації про результати власної навчальної (наукової, творчої) діяльності, використані методики досліджень і джерела інформації);

$>$ основна та додаткова література, яка необхідна для користування під час вивчення даного курсу дисципліни; посилання на сторінку електронного навчально-методичного комплексу дисципліни.

\section{ОБГОВОРЕННЯ}

Досвід використання силабусів з дисципліни «Фізика» дозволяє нам визначити основні методичні засади їх створення. Так, навчальний матеріал слід розподіляти по окремих змістовних блоках, кожний з яких передбачає досягнення конкретної дидактичної мети. Силабус слід будувати таким чином, щоб інтеграція освітніх цілей усіх блоків забезпечувала запланований результат у вивченні фізики. Відповідно, до змісту навчального матеріалу в межах кожного блоку необхідно визначити види і форми освітнього процесу як для аудиторної, так і для самостійної діяльності студентів. При цьому особливо слід урахувати той факт, що усі ці види і форми навчання повинні інтегруватися у тих або інших співвідношеннях для досягнення освітніх цілей на кожному конкретному етапі. Необхідно передбачити також можливості зміни змісту блоків навчального матеріалу з урахуванням практичних потреб. Навчальна інформація повинна відображати динаміку розвитку будівельної галузі, при цьому навчальний матеріал повинен бути цілісним, а структура інформації логічною, коли кожний наступний елемент змісту випливає з попереднього.

Однією з важливих особливостей силабусу є те, що він слугує своєрідним провідником для кожного студента на шляху досягнення запланованих освітніх цілей та результатів навчання. Таким чином, силабус забезпечує розширення мотиваційної сфери студента, спонукає його до більш усвідомленого опанування змісту курсу фізики. Використання силабусу також передбачає для кожного студента можливості вибору форм взаємодії з викладачем та зі студентським колективом у ході засвоєння навчальної інформації. Залежно від уподобань та індивідуальних особливостей студента можливий вибір альтернативних моделей навчання з урахуванням попереднього ретельного розроблення шляхів їх успішної реалізації. Силабус складається таким чином, що до певного рівня засвоєння знань студент здатний працювати повністю самостійно з урахуванням його пропедевтичних знань, при цьому викладач виконує лише консультативні дії та у разі необхідності спрямовує роботу студента. Але у разі виникнення ускладнень повинна бути передбачена можливість спільного вибору викладачем і студентом шляхів розв'язання навчальних проблем. Також в умовах роботи за силабусом студент самостійно робить вибір, чи потрібне йому зовнішнє керування, чи він перейде на рівень самокерування. Відповідно до вимог освітнього стандарту, для кожного змістовного блоку силабусу складається перелік знань і умінь, які студент повинен опанувати. Необхідною умовою успішного досягнення запланованих результатів навчання $\epsilon$ створення методичних матеріалів для формування елементів навчально-пізнавальної діяльності, а також їх систематизації i узагальнення при переході до моделей продуктивного навчання.

\section{ВИСНОВКИ ТА ПЕРСПЕКТИВИ ПОДАЛЬШОГО ДОСЛІДЖЕННЯ}

Отже, використання силабусу дозволяє студенту самостійно опанувати зміст навчального матеріалу при переході від одного змістовного блоку до іншого, а також пройти процедури запланованого контролю. Силабус передбачає інтегративні методики контролю і оцінювання освітніх результатів, що дозволяє індивідуалізувати та диференціювати освітній процес. Варто відзначити, що силабус є важливим компонентом дидактичного забезпечення, а тому вимагає постійного удосконалення з метою забезпечення якості навчання. Освітня ефективність силабусу та його педагогічна доцільність визначаються на основі діагностики динаміки студента у його професійно-особистісному розвитку, оволодіння способами навчального пізнання та їх застосування у конкретних навчальних ситуаціях, а також у змодельованих професійних ситуаціях. Слід наголосити, що силабус є важливим засобом на шляху розв'язання однієї з головних проблем сучасної професійної освіти - неузгодженості між їі гуманістичними цілями та нормативними вимогами стандарту вищої освіти до компетентності інженера-будівельника, а також відсутністю системи моніторингу результативності освітнього процесу загалом. Можна із впевненістю стверджувати - якщо студент усвідомлено будує свою освітню траєкторію за силабусом, то він буде в змозі не лише досяпи високий рівень фахової компетентності, але й опанувати різнобічні методологічні знання, які в подальшому дозволять йому прогнозувати, реалізовувати та аналізувати свою професійну діяльність.

\section{СПИСОК ВИКОРИСТАНИХ ДЖЕРЕЛ}

1. Дмитриченко, М.Ф., Хорошун, Б.І., Язвінська, О.М., \& Глушенок, Н.М. (2010). Фундаментальність освіти та ії роль у підготовці інноваційно орієнтованих фахівців. Вісник Національного транспортного університету, 21(1), 3-7.

2. Ваганова, О.И., Хижная, А.В., Трутанова, А.В., Гладкова, М.Н., \& Лунева, Ю.Б. (2016). Силлабус как средство организации самостоятельной работы студентов. Международный журнал прикладных и фундаментальных исследований, 11-5, 968-970.

3. Заболотний, В.Ф. (2009). Методика навчання фізики. Загальні питання (в схемах і таблицях з мультимедійними додатками. 112с.

4. Іщенко, Р.М., \& Ісаєнко, Г.Л. (2019). Аналіз рівня підготовки з фізики студентів технічних спеціальностей за результатами вхідного контролю. Фізико-математична освіта, 1(19), 75-79. https://doi.org/10.31110/2413-1571-2019-019-1-012.

5. Петрук, В.А. (2006). Теоретико-методичні засади формування професійної компетентності майбутніх фахівців технічних спеціальностей у процесі вивчення фундаментальних дисциплін : монографія. Вінниця : Універсум-Вінниця.

6. Петруньок, Т., \& Благодаренко, Л. (2021). Інноваційні технології будівництва в освітньому процесі з фізики у закладах вищої будівельної освіти. Наукові записки Бердянського державного педагогічного університету. Серія : Педагогічні науки, 1, 303-310. https://doi.org/10.31494/2412-9208

7. Петруньок, Т.Б. (2015). Особливості навчання фізики у будівельних вищих навчальних закладах. Наукові записки Бердянського державного педагогічного університету. Педагогічні науки, 2, 233-238.

8. Чепурна, C. (2020). Силабус як засіб організації самостійної роботи студентів. http://www.aphnjournal.in.ua/archive/27_2020/part_5/27-5_2020.pdf\#page=215. 
9. Gnitetskaya, T. (2014). Modeling of interdisciplinary connections in science courses. Journal of Physics: Conf. Ser., 012068 (4), 490. https://doi.org/10.1088/1742-6596/490/1/012068.

10. Richard, V. N. (2015). Interdisciplinary research by the numbers. Nature, 525, 306-307. https://doi.org/10.1038/525306a.

11. Москов, В.А. (2016). Інформаційне освітнє середовище як засіб фахової підготовки майбутніх кваліфікованих робітників будівель ного профілю. Фізико-математична освіта, 4(10), 89-94. https://fmo-journal.fizmatsspu.sumy.ua/publ/3-1-0-121

\section{REFERENCES (TRANSLATED AND TRANSLITERATED)}

1. Dmytrychenko, M.F., Khoroshun, B.I., Yazvinska, O.M., \& Hlushenok, N.M. (2010). Fundamentalnist osvity ta yii rol u pidhotovtsi innovatsiino oriientovanykh fakhivtsiv [Fundamentality of education and its role in the training of innovation-oriented professionals]. Visnyk Natsionalnoho transportnoho universytetu - Bulletin of the National Transport University, 21(1), 3-7 (in Ukrainian).

2. Vahanova, O.Y., Khyzhnaia, A.V., Trutanova, A.V., Hladkova, M.N., \& Luneva, Yu.B. (2016). Sylabus yak zasib orhanizatsii samostiinoi roboty studentiv [Syllabus as a means of organizing independent work of students]. Mizhnarodnyy zhurnal prykladnykh ta fundamental'nykh doslidzhen' - International Journal of Applied and Basic Research, 11-5, 968-970 (in Russian).

3. Zabolotnyi, V.F. (2009). Metodyka navchannia fizyky. Zahalni pytannia (v skhemakh i tablytsiakh z multymediinymy dodatkamy) [Methods of teaching physics. General questions (in diagrams and tables with multimedia applications)]. (in Ukrainian).

4. Ishchenko, R.M., \& Isaienko, H.L. (2019). Analiz rivnia pidhotovky z fizyky studentiv tekhnichnykh spetsialnostei za rezultatamy vkhidnoho kontroliu [Analysis of the level of training in physics of students of technical specialties according to the results of input control]. Fizykomatematychna osvita - Physical and mathematical education, 1 (19), 75-79. https://doi.org/10.31110/2413-1571-2019-019-1-012 (in Ukrainian).

5. Petruk, V.A. (2006). Teoretyko-metodychni zasady formuvannia profesiinoi kompetentnosti maibutnikh fakhivtsiv tekhnichnykh spetsialnostei u protsesi vyvchennia fundamentalnykh dystsyplin : monohrafiia [Theoretical and methodological principles of formation of professional competence of future specialists of technical specialties in the process of studying fundamental disciplines: monograph]. Vinnytsia : Universum-Vinnytsia. (in Ukrainian).

6. Petrunok, T., \& Blahodarenko, L. (2021). Innovatsiini tekhnolohii budivnytstva v osvitnomu protsesi z fizyky u zakladakh vyshchoi budivelnoi osvity [Innovative construction technologies in the educational process in physics in institutions of higher construction education]. Naukovi zapysky Berdianskoho derzhavnoho pedahohichnoho universytetu. Seriia: Pedahohichni nauky - Scientific Notes of the Berdyansk State Pedagogical University. Series: Pedagogical sciences, 1, 303-310. https://doi.org/10.31494/2412-9208 (in Ukrainian).

7. Petrunok, T. (2015). Osoblyvosti navchannia fizyky u budivelnykh vyshchykh navchalnykh zakladakh [Features of teaching physics in construction higher education institutions]. Naukovi zapysky Berdianskoho derzhavnoho pedahohichnoho universytetu. Pedahohichni nauky - Scientific Notes of the Berdyansk State Pedagogical University. Pedagogical sciences, 2, 233 - 238 (in Ukrainian).

8. Chepurna, S. (2020). Sylabus yak zasib orhanizatsii samostiinoi roboty studentiv [Syllabus as a means of organizing independent work of students]. URL : http://www.aphnjournal.in.ua/archive/27_2020/part_5/27-5_2020.pdf\#page=215 (in Ukrainian).

9. Gnitetskaya, T. (2014). Modeling of interdisciplinary connections in science courses. Journal of Physics: Conf. Ser., 012068 (4), 490. https://doi.org/10.1088/1742-6596/490/1/012068 (in Russian).

10. Richard, V. N. (2015). Interdisciplinary research by the numbers. Nature, 525, 306-307. https://doi.org/10.1038/525306a.

11. Moskov, V.A. (2016). Informatsiine osvitnie seredovyshche yak zasib fakhovoi pidhotovky maibutnikh kvalifikovanykh robitnykiv budivelnoho profiliu [Information educational environment as means of vocational training of future skilled workers building profile]. Fizykomatematychna osvita - Physical and Mathematical Education, 4(10), 89-94. https://fmo-journal.fizmatsspu.sumy.ua/publ/3-1-0-121 (in Ukrainian).

\section{(cc) $\mathrm{BY}-\mathrm{NC}-\mathrm{SA}$}

This work is licensed under Creative Commons Attribution-NonCommercial-ShareAlike 4.0 International License. 